Bu makaleye atıfta bulunmak için/To cite this article:

ERÇETIN, Ș. Ș. (2021). The Effectiveness of Health Management in Schools Scale (EHMSS): A Validity and Reliability Study. Atatürk Üniversitesi Sosyal Bilimler Enstitüsü Dergisi, 25 (3), 1050-1066.

\title{
The Effectiveness of Health Management in Schools Scale (EHMSS): A Validity and Reliability Study
}

\author{
Şefika Şule ERÇETIN ${ }^{(*)}$
}

\begin{abstract}
The aim of this study is to develop a valid and reliable measurement tool that can measure the effectiveness of health management at schools according to teachers' opinions. The study group of the research consists of teachers working in pre-school, primary, secondary and high schools in Çankaya district of Ankara in fall semester 2019. In this study, exploratory factor analysis (EFA) and confirmatory factor analysis (CFA) were used to analyze the data. The findings of EFA and CFA were obtained from two different study groups consisted of 387 and 283 people respectively selected by simple random sampling method, which is a probabilistic sampling method. To this end, the scale consisted of 22 items and 4 sub-dimensions was formed. CFA that was conducted to determine the construct validity revealed that the model fit values of the scale were appropriate. The sub-dimensions of the scale were 'Food and Equipment Health, Hygiene Health, Awareness and Physical Space, and Environmental Health'. The scale had four items coded in reverse. A total score was obtained from EHMSS and its dimensions, and the high score obtained from the scale means that the effectiveness level of health management at school is high, and the low score obtained means that the effectiveness level of health management at school is low. Cronbach's Alpha reliability coefficient of the scale indicated that the scale is a reliable measurement tool. Results and findings overall indicated that 'Effectiveness of Health Management in Schools Scale (EHMSS)' is a valid and reliable measurement tool that can be used psychometrically.
\end{abstract}

Keywords: Health management in schools, health management, effectiveness of health management, scale development

Öz: Bu çalışmanın amacı, okullarda sağllk yönetiminin etkililiğini öğretmen görüşlerine göre ölçebilecek geçerli ve güvenilir bir ölçme aracı geliştirmektir. Araştırmanın çalışma grubunu 2019 güz döneminde Ankara ili Çankaya ilçesinde okul öncesi, ilkokul, ortaokul ve liselerde görev yapan ögretmenler oluşturmaktadır. Bu çalışmada verileri analiz etmek için açımlayıcı faktör analizi (AFA) ve doğrulayıcı faktör analizi (DFA) kullanılmıştır. AFA ve DFA bulguları, olasılıklı örnekleme yöntemlerinden basit tesadüfi örnekleme yöntemi ile seçilen siraslyla 387 ve 283 kişiden

\footnotetext{
*) Prof. Dr., Hacettepe Üniversitesi Eğitim Yönetimi Bilim Dalı (e-posta: sefikasule@gmail.com) (D) ORCID ID. https://orcid.org/0000-0002-7686-4863

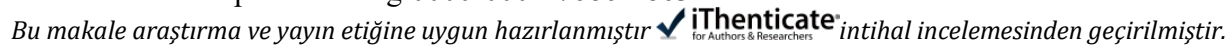


oluşan iki farklı çalışma grubundan elde edilmiştir. Bu amaçla ölçek 22 maddeden ve 4 alt boyuttan oluşturulmuştur. Yapı geçerliliğini belirlemek için yapılan DFA, ölçeğin model uyum değerlerinin uygun olduğunu ortaya koymuştur. Ölçeğin alt boyutlarl "Gıda ve Ekipman Sağllğg, Hijyen Sağlı̆̆l, Farkındalık ve Fiziksel Mekân ve Çevre Să̆lı̆̆ı”dır. Ölçekte ters kodlanmış dört madde bulunmaktadır. EHMSS ve boyutlarından toplam puan elde edilmiş olup, ölçekten alınan yüksek puan okulda sağllk yönetiminin etkililik düzeyinin yüksek, düşük puan ise okulda sağllk yönetiminin etkililik düzeyinin düşük olduğu anlamına gelmektedir. Ölçeğin Cronbach's Alpha güvenirlik katsayısı, ölçeğin güvenilir bir ölçme aracı olduğunu göstermiştir. Sonuç ve bulgular genel olarak “Okullarda Sağlık Yönetiminin Etkililiği Ölçeği (EHMSS)"nin psikometrik olarak kullanılabilecek geçerli ve güvenilir bir ölçme aracı olduğunu göstermiştir.

Anahtar Kelimeler: Okullarda sağlık yönetimi, sağlık yönetimi, sağlık yönetiminin etkililiği, ölçek gelişstirme.

Makale Gelis Tarihi: 12.06.2021

Makale Kabul Tarihi: 23.09.2021

DOI: 10.53487/ataunisosbil.951309

\section{Introduction}

Health services provided for children are one of the fundamental rights that children should have. In other words, protecting individuals from all kinds of negative external factors and creating appropriate conditions to protect their health is the fundamental health right of every child (Johansen et al., 2006; Watson, 2008). In the context of school, realizing the requirements concerning school health has accelerated the initiatives to ensure school health (Kub \& Steel, 2000). These initiatives have contributed to the school environments to provide opportunities for the mental and social development of children (Croghan \& Johnson, 2004). Therefore, it can be said that providing a healthy school environment is the duty and responsibility of school administrations or administrators. In another saying, that to be able to perform an effective health management in the schools where they work is one of the main duties and responsibilities of the administrators.

Health management is defined as the efficient and effective use of available health resources (Adindu, 2013). Similarly, it is also described as the activities of planning, organizing, directing, coordinating and evaluating all available resources within the organizational framework (Ulusoy et al., 2014). Strong leaders with effective leadership skills are needed for an effective health management. Because effective leadership is one of the fundamental competence areas that are considered important in almost all organizations (Thompson, 2012). The existence of an effective health management in organizations with many stakeholders like schools is possible if school administrators make health management functional at their schools. According to Gençoğlu and Kuşkaya (2017), the existence of a functional health management can have direct positive reflections on human capital. School administrators, by ensuring the effectiveness of health management at schools they manage, and considering the 
relationship between education and health, can contribute to positive reflections on students.

The fact that there is a direct relationship between educational attainments and health outcomes and understanding that students who study under appropriate health conditions have higher academic achievements point to the necessity of health management at schools (Bundy et al., 2017; Durlak et al., 2011; Murray et al., 2007; Shackleton et al., 2016). Giving importance to the social and emotional health of all students in countries such as Australia, Singapore, Sweden and Finland, where students' academic success is high, can be seen as concrete examples of the health and education relationship (Bonell et al., 2014). A healthy school environment, which has the characteristic of affecting other dimensions related to education as well as its academic dimension, can be a determinant in ensuring equal success and equal opportunity in education systems (Oral \& Mcgivney, 2014). Thus, a healthy and clean school environment can affect the whole learning-teaching processes positively.

"School Health Services Cooperation Protocol" was signed between the Turkish Ministry of National Education (MEB) and the Ministry of Health (SB) in 2016 in order to increase the effectiveness of health management at schools. With this protocol, a school health model was created by drawing the framework of the projects and studies that have been or will be carried out within the scope of school health at schools. According to the protocol, healthy school studies were determined under the headings of "healthy and safe school environment, healthy nutrition, health education, physical activity, health services, family and community participation" (MEB \& SB, 2016). Accordingly, it is understood that school administrators have important roles in establishing a healthy school in line with the "Health Protection and Improvement Program at School". They have to establish an effective and efficient health management with their managerial responsibilities in healthy school studies.

Considering that an important part of individuals' lives are spent in various educational organizations, schools have a critical importance in terms of protecting or improving their health (Baltaş, 2004; Bektaş \& Öztürk, 2008). Theoretical and empirical studies on school health in the literature also support this inference (Babayiğit et al., 2010; Bulduk, 2002; Claing \& Rossor,1999; Constante, 2001; Çakır, 2005; Dağdeviren, 2010; Hatipoğlu, 2016; Koçoğlu, 2011; Marmaris, 2004; Mumcu, 1999; Özcan et al., 2013; Özyurt et al., 2005; Pelin Başar, 2008; Serim \& Aslan, 1991; Soysal et al., 2008; Şahinöz et al., 2017; Tezel \& Yaman, 1998; Usta, 2008; Yiğit, 1992). However, the absence of research examining or addressing the health management effectiveness of schools among these studies can be interpreted as a gap in the literature. Since this research aims to develop a measurement tool that can measure the health management effectiveness of schools, it can contribute to reach more valid and reliable information about the health management effectiveness of schools. Besides, this study can be regarded important in determining what level of health management the schools have. In this context, the current research aims to develop a valid and reliable scale that can determine the effectiveness of health management at schools, and its main scope is to the 
answer to the question 'To what extent is the Effectiveness of Health Management at Schools Scale (EHMSS) valid and reliable?

\section{Method}

In this part, the information about the research model, study group, data collection tool, data collection and data analysis is presented.

\section{A. Research Model}

This research is a quantitative scale development study carried out in a screening model. Screening model is a research model that describes a current situation as it exists without any change or intervention in order to reach a general conclusion about the universe (Karasar, 2012). In this research, a validity and reliability study of the EHMSS was conducted.

\section{B. Study Group}

The study group of the research consists of teachers working in pre-school, primary, secondary and high schools in Çankaya district of Ankara, in the fall semester 2019. In the study, the findings of exploratory factory analysis (EFA) and confirmatory factor analysis (CFA) were obtained from two different study groups consisted of 387 and 283 people respectively selected by simple random sampling method, which is a probabilistic sampling method.

The study group for EFA consisted of 387 teachers, $39.8 \%(\mathrm{n}=154)$ were male and $60.2 \%(\mathrm{n}=233)$ were female; $15 \%(\mathrm{n}=58)$ were working in preschool, $28.9 \%(\mathrm{n}=112)$ in primary school, $30 \%(\mathrm{n}=116)$ in secondary school, $26.1 \%(\mathrm{n}=101)$ in high school. The years of seniority were $29.2 \%(\mathrm{n}=113) 1-10$ years, $42.9 \%(\mathrm{n}=166) 11-20$ years, $27.9 \%(n=108) 21$ years and above.

The study group for CFA consisted of 283 teachers, $42.8 \%(n=121)$ were male and $57.2 \%(\mathrm{n}=162)$ were female; $14.8 \%(\mathrm{n}=42)$ were working in preschool, $32.5 \%(\mathrm{n}=$ 92) in primary school, $30.4 \%(\mathrm{n}=86)$ in secondary school, $22.3 \%(\mathrm{n}=63)$ in high school. The years of seniority were $29 \%(\mathrm{n}=82) 1-10$ years, $47.3 \%(\mathrm{n}=134) 11-20$ years, and $23.7 \%(n=67) 21$ years and above. 670 teachers participated in all stages of the research in total. In the literature, it is stated that in scale development studies, the number of participants should be between 200 and 300 (Comrey \& Lee, 1992) or the sample number should be at least five or ten times the number of items (Bryman \& Cramer, 2001). In this context, it can be said that the EFA $(n=387)$ and CFA $(n=283)$ sample sizes of this study are sufficient.

\section{Data Collection Tool}

In order to develop a valid and reliable measurement tool that can measure the effectiveness of health management at schools, a draft scale form of 49 items in 5-point Likert type was prepared initially. In the process of creating the item pool of the scale, the relevant domestic and international literature was used and care was taken to include the dimensions of physical space, environment, school stakeholders (students, teachers 
and parents), hygiene, awareness, food, equipment and safety, which are related to health management in schools. The items in the draft scale form were presented to the opinion of 4 experts in the field and 2 language experts. Accordingly, the draft form of the scale was reduced from 49 to 35 items by removing overlapping items and the ones not measuring the features desired.

The pilot study of the 35-item draft scale, was applied to a sample group of 38 people, including 5 school principals, 7 vice principals and 26 teachers. Following the pilot application, it was determined that some expressions in the draft scale form did not serve the purpose due to having long structures or multiple meanings. The feedback provided from the pilot application was also presented to the opinions of the field and language experts. The items and statements in the scale were revised and the final form of 30 -item scale was given for the main application. The scale was named as the Effectiveness of Health Management in Schools Scale (EHMSS) and was prepared in 5-point Likert as (1) I strongly disagree, (2) I disagree, (3) I partially agree, (4) I agree, (5) I strongly agree. In addition, demographic questions for the participants (gender, education level and professional seniority) were included in the introductory chapter of the scale.

\section{Data Collection}

The research data were collected with the prepared scale form. In the first part of the scale form, there were explanations stating that the research was voluntary and that the research results would only be used for scientific purposes. In addition, the participants were informed that they could leave the study at any time and were asked to approve the 'Informed Consent Form'. E-mail addresses and telephone numbers of the researchers were also included in the introductory chapter of the scale form in order to provide the necessary explanations on incomprehensible issues regarding the study.

\section{E. Data Analysis}

Before the analyses, the data collected were examined whether there were incorrect entries, missing values and extreme values in the scale items. After it was assured that there were no wrong or missing values in the study, normality analysis of the data set was made. The $Z$-standard scores of the data set $[-3<Z<+3]$ were calculated, and in the further steps, 5 outliers for EFA and 7 outliers for CFA were removed from the scale. The normality assumptions of the study were checked according to Kurtosis and Skewness values (see Table 1).

EFA and CFA were performed, in given order, to determine the construct validity of the EHMSS. Principal component analysis and varimax vertical rotation method were used in EFA, and maximum likelihood analysis was used in the CFA. Prior to EFA, which was the first phase of the research, whether the research data were suitable for EFA was determined by Kaiser-Meyer-Olkin (KMO) coefficient and Bartlett Sphericity test analyzes. In EFA, criteria such as common factor variance, item eigenvalues at least 1, at least .10 difference between overlapping items, item factor loads and item total correlations at least .30, explained variance ratio, elimination of items that do not 
measure the same structure, and the ability to represent theoretical foundation that is desired to measure were taken into account.

In the second part of the study, CFA was conducted in order to determine the modeldata fit of the findings obtained in EFA. In CFE analysis, goodness of fit indices, which are commonly accepted in the literature, were taken into account. Accordingly, in the literature, it is stated that the fit values' $\chi^{2}$ / sd ratio must be less than 4, RMSEA and RMR values must be less than .08, CFI, NFI, NNFI, IFI, RFI values must be .90 and above, AGFI and GFI values must be .85 and above (Brown, 2006; Byrne, 2001; Çelik, 2009; Hair et al., 2014; Kline, 2005; Meydan \& Şeşen, 2011; Schermelleh-Engel \& Moosbrugger, 2003; Tabachnick \& Fidell, 2013). Cronbach's Alpha internal consistency coefficient was calculated for the reliability of the scale and all validity and reliability analyzes were reported using SPSS 21.00 and AMOS 23.00 statistical package programs.

\section{Findings}

This section consists of the descriptive analysis, EFA, CFA and reliability analysis findings of the scale.

\section{A. Descriptive Analysis Findings of the Scale}

The descriptive analysis findings regarding EFA and DFA of the EHMSS are given in Table 1.

Table 1. Descriptive statistical findings for EFA and CFA ( $\left.\mathrm{n}_{\mathrm{EFA}}=387, \mathrm{n}_{\mathrm{CFA}}=283\right)$

\begin{tabular}{lcc}
\hline \multicolumn{2}{l}{ Descriptive Statistical Analysis of EFA } & Descriptive Statistical Analysis of CFA \\
\hline Mean & 4.26 & 4.34 \\
Median & 4.27 & 4.45 \\
Mode & 5.00 & 4.91 \\
Standard Deviation & .56 & .50 \\
Variance & .31 & .25 \\
Skewness & -.45 & -.76 \\
Kurtosis & -.70 & -.06 \\
Minimum & 2.91 & 2.91 \\
Maximum & 5.00 & 5.00 \\
\hline
\end{tabular}

As seen in Table 1, the mean of EFA research data is 4.26 , the median is 4.27 , the mode is 5.00 , the standard deviation is .56 , the variance is .31 , the Skewness value is .45 , the Kurtosis value is -.70 , the minimum score is 2.91 , and the maximum score is 5.00. The mean of the CFA research data is 4.34 , the median is 4.45 , the mode is 4.91 , the standard deviation is .50, the variance is .25 , the Skewness value is -.76 , the Kurtosis value is -.06 , the minimum score is 2.91 , and the maximum score is 5.00 . According to Table 1, the fact that the mean, median and mode of the scale are considerably close to each other, and the Kurtosis and Skewness values are in the range of $-1.5,+1.5$ means that the EFA and DFA data show normal distribution (Tabachnick \& Fidell, 2013). 


\section{B. EFA Findings}

In order to determine the suitability of the research data for EFA, Kaiser-Meyer-Olkin (KMO) and Bartlett Sphericity test findings were examined. Accordingly, KMO value was .93 and Bartlett's Test of Sphericity $[\chi 2=5416.833$; sd $=231 ; \mathrm{p}<.01]$ was determined to be meaningful. That the KMO value was greater than .60 and the Bartlett test was meaningful were considered as indication that the data were suitable for EFA and were normally distributed (Bayram, 2013). After the research data was determined to be suitable, EFA was performed according to the rotated principal component analysis method.

In scale development studies, it is recommended that the item correlations for the items in the scale should be at least .30 or above, and the items should not exist in more than one factor (Tavşanc1l, 2010). The main criterion for entering different factors is the difference of at least .10 between the factor loads of the scale items. In other words, items with a difference of less than .10 between the load values of the scale items in different factors are accepted as overlapping items and removed from the scale (Yavuz, 2005). Besides, in scale development, in order for any item to be included in the scale, a factor load value greater than .40 is considered a good preference (Şencan, 2014). In this context, items with item common variance value and item total correlation below .30 and items with item factor load value less than .40 and items with a difference of less than .10 in different factor load values were excluded from the scale in this study.

According to the EFA results of the study, 1 item with a common variance value below .30, 3 items with an item factor load below .40, and 4 overlapping items with a high load value in more than one factor were excluded from the scale. Thus, according to the principal components analysis, 22 items in the scale were gathered under 4 subfactors that were compatible in terms of meaning and content and whose eigenvalues were greater than 1. The scree plot resulting from the analysis is shown in Figure.

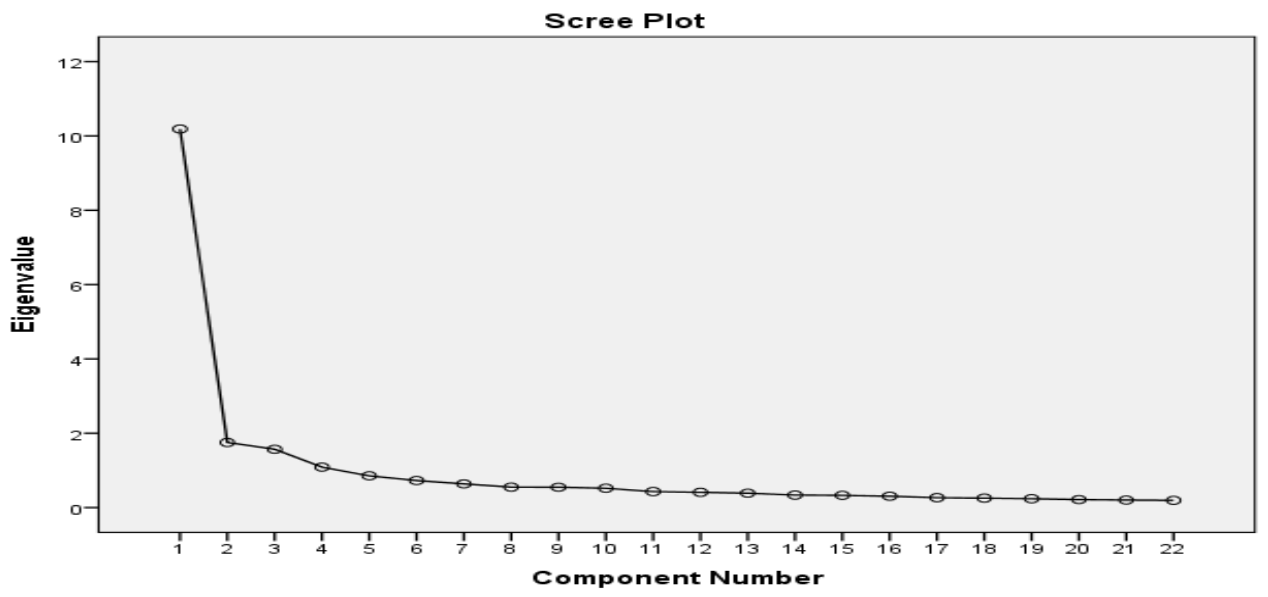

Figure 1. Scree Plot for The Scale 
In Figure 1, when the scree plot is examined, it is clearly seen that the components of the $\mathrm{Y}$ axis descend towards the components of the $\mathrm{X}$ axis and from the 5th point the contribution of the components to the variance remains constant. Therefore, it was decided that the number of factors should be 4 . Distribution of scale items according to dimensions, item factor load values, common variance value, item total correlations, eigenvalues, variance ratios explained by the factors and total variance values are given in Table 2.

Table 2. EFA Findings of the Scale

\begin{tabular}{|c|c|c|c|c|c|c|}
\hline Item & $\begin{array}{c}\text { Factor } \\
1\end{array}$ & $\begin{array}{c}\text { Factor } \\
2\end{array}$ & $\begin{array}{c}\text { Factor } \\
\mathbf{3}\end{array}$ & $\begin{array}{c}\text { Factor } \\
4\end{array}$ & $\begin{array}{c}\text { Common } \\
\text { Variance Value }\end{array}$ & $\begin{array}{l}\text { Item Total } \\
\text { Correlation }\end{array}$ \\
\hline M1 & .69 & & & & .58 & .61 \\
\hline M2 & .73 & & & & .64 & .62 \\
\hline M3 & .74 & & & & .67 & .68 \\
\hline M4 & .73 & & & & .65 & .63 \\
\hline M5 & .71 & & & & .62 & .64 \\
\hline M6 & .70 & & & & .63 & .60 \\
\hline M7 & .66 & & & & .57 & .62 \\
\hline M8 & & .74 & & & .73 & .66 \\
\hline M9 & & .78 & & & .75 & .63 \\
\hline M10 & & .77 & & & .76 & .64 \\
\hline M11 & & .70 & & & .69 & .65 \\
\hline M12 & & & .63 & & .61 & .66 \\
\hline M13 & & & .74 & & .71 & .63 \\
\hline M14 & & & .79 & & .78 & .64 \\
\hline M15 & & & .75 & & .74 & .67 \\
\hline M16 & & & & .69 & .63 & .65 \\
\hline M17 & & & & .44 & .62 & .71 \\
\hline M18 & & & & .46 & .49 & .63 \\
\hline M19 & & & & .74 & .70 & .68 \\
\hline M20 & & & & .80 & .69 & .56 \\
\hline M21 & & & & .72 & .67 & .64 \\
\hline M22 & & & & .71 & .63 & .60 \\
\hline Eigenvalue & 10.187 & 1.752 & 1.568 & 1.088 & & \\
\hline $\begin{array}{l}\text { Explained } \\
\text { Variance } \\
(\%)\end{array}$ & 46.303 & 7.964 & 7.129 & 4.947 & $\begin{array}{l}\text { Explained Total } \\
\text { Variance (\%) }\end{array}$ & 66.343 \\
\hline
\end{tabular}

As seen in Table 2, the items in the scale were gathered in 4 independent dimensions. The factor loading values of the items vary between .44 and .80 ; common variance values 
vary between .49 and .76 and item total correlation values vary between .60 and .71 . In terms of eigenvalues, the first factor was 10.187 , the second factor was 1.752 , the third factor was 1.568 , and the fourth factor was 1.088 . The variance rate explained by each factor was $46.303 \%, 7.964 \%, 7.129 \%, 4.947 \%$ in the first, second, third and fourth factors respectively. The total variance rate explained by the four factors is $66.343 \%$. Thus, as a result of the analysis, a 22 -item measurement tool was created. The 4 subfactors emerged as a result of the EFA were named as dimensions, considering the contents of the items that make up each factor. In this framework, there were 7 items in the Food and Equipment Health dimension (items 1, 2, 3, 4, 5, 6, 7); 4 items in the Hygiene Health dimension (items 8, 9, 10, 11); 4 items in the Awareness dimension (items 12, 13, 14, 15); 7 items in the Physical Space and Environmental Health dimension (items 16, 17, 18, 19, 20, 21 and 22). In the scale 1st, 10th, 19th and 22nd items had to be coded in reverse. A total score can be obtained from all of the scale and its dimensions, and the high score obtained from the scale means that the effectiveness level of health management at the school is high, and a low score means that the effectiveness level of health management at the school is low.

\section{CFA Findings}

In order to determine the validity of the 4-dimensional structure of the scale determined by EFA, goodness of fit values related to the model were obtained by performing CFA with AMOS 23.00 package program. In this context, the results obtained as a result of CFA of the EHMSS consisting of 22 items are given in Figure 2.

As seen in Figure 2, item load values of the scale in Food and Equipment Health dimension vary between .64 and .78 ; in the Hygiene Health dimension between .75 and .79 ; in the Awareness dimension between .70 and .82; in the Physical Space and Environmental Health dimension between .60 and .79; and it ranges from .60 to .82 for the EHMSS. According to the CFA results, all items of the scale were found to be significant at $\mathrm{p}<.01$ level in terms of $t$ values. However, two modifications were made between items M6-M7 and M21-M22 to ensure that the model fit goodness values of the scale were more appropriate. The model fit goodness values of the research data as a result of CFA are given in Table 3.

It is known that the goodness of fit values commonly used in the literature are $\mathrm{x} 2 / \mathrm{df}$, RMSEA, RMR, SRMR, AGFI, GFI, CFI, NFI, NNFI / TLI, and IFI (Meydan \& Şeşen, 2011; Şimşek, 2007). For the acceptable limit in terms of goodness of fit indices, $x 2$ / sd value must be less than 5, RMSEA, RMR, SRMR values must be .08 or less, AGFI, GFI and NFI values must be greater than .85 , CFI, NNFI / TLI and IFI values must be greater than 90 (Arbuckle, 2007; Brown, 2006; Marcoulides \& Schumacher, 2001; Sümer, 2000; Tabachnick \& Fidell, 2013). Accordingly, as seen in Table 3, the goodness of fit values calculated for this study $(\mathrm{x} 2 / \mathrm{sd}=474.006 / 201=2.358<3, \mathrm{RMSEA}=.069$, $\mathrm{RMR}=.037, \mathrm{SRMR}=.060, \mathrm{AGFI}=.86, \mathrm{GFI}=.89, \mathrm{CFI}=.92, \mathrm{NFI}=.86, \mathrm{NNFI} / \mathrm{TLI}=.90$, $\mathrm{IFI}=.92$ ) indicated that the research model had construct validity in the ranges accepted in the literature and the four-dimensional structure of the scale has been verified. 


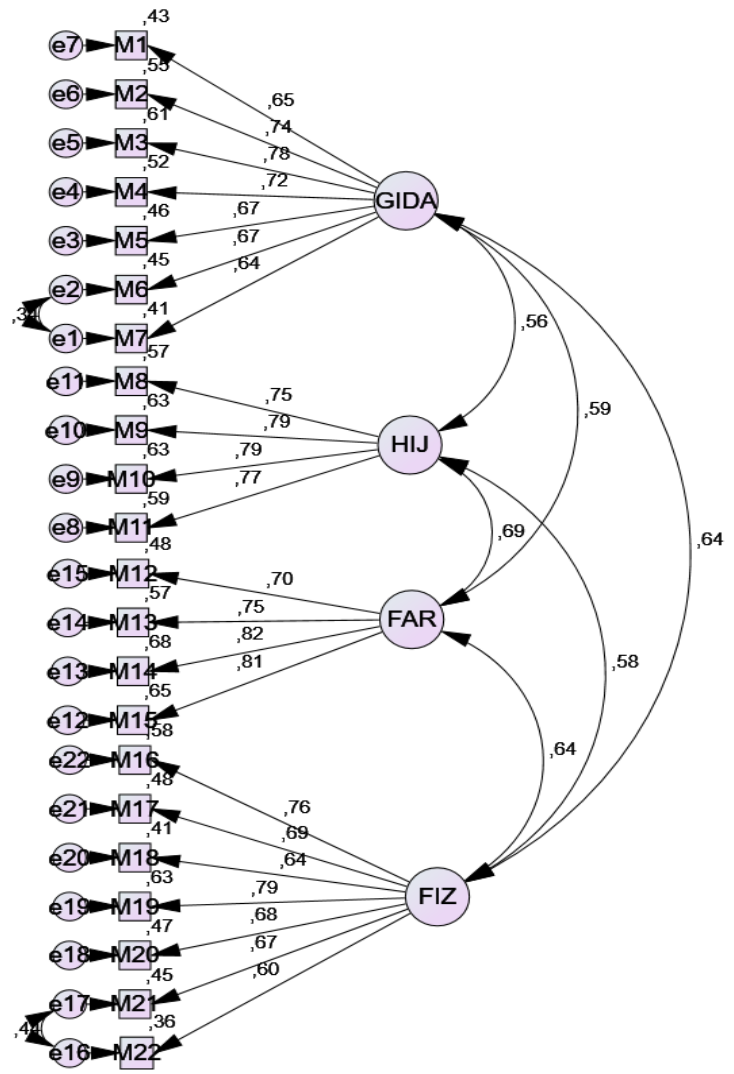

Figure 2. Sub-Dimension DFA Model of the Scale

Table 3. Model Fit Goodness Values of the Scale

\begin{tabular}{cc}
\hline Fit Values & $\begin{array}{c}\text { Goodness of Fit Values of this } \\
\text { Research }\end{array}$ \\
\hline $\mathrm{p}$ & .000 \\
$\chi^{2} / \mathrm{sd}$ & $474.006 / 201=2.358$ \\
RMSEA & .069 \\
RMR & .037 \\
SRMR & .060 \\
AGFI & .86 \\
GFI & .89 \\
CFI & .92 \\
NFI & .86 \\
NNFI (TLI) & .90 \\
IFI & .92 \\
\hline
\end{tabular}


The Effectiveness of Health Management in Schools Scale (EHMSS):Validity and Reliability Study

\section{Reliability Analysis Findings}

Reliability analysis of EHMSS was determined by calculating Cronbach's Alpha reliability coefficients which are given in Table 4.

Table 4. Cronbach's Alpha reliability coefficients of the scale

\begin{tabular}{lcc}
\hline Dimensions & $\begin{array}{c}\text { Number of } \\
\text { Items }\end{array}$ & $\begin{array}{c}\text { Cronbach's Alpha Reliability } \\
\text { Coefficient }\end{array}$ \\
\hline Food and Equipment Health & 7 & .87 \\
Hygiene Health & 4 & .85 \\
Awareness & 4 & .84 \\
Physical Space and Environmental Health & 7 & .86 \\
Entire Scale & 22 & .92 \\
\hline
\end{tabular}

According to Table 4, it was determined that the Cronbach's Alpha reliability coefficient varied between .84 and .92 in all sub-dimensions of the scale and in EHMSS. Considering that the reliability coefficient of the measurement tools is .70 and higher in terms of the reliability of the scale data (Hair et al., 2014), it can be said that all subdimensions of the scale and the EHMSS are reliable. Moreover, the Pearson Product Moments correlation values between the dimensions of the scale are given in Table 5.

Table 5. Correlation values between the dimensions of the scale and the whole

\begin{tabular}{lcccc}
\hline Dimensions & $\mathbf{1}$ & $\mathbf{2}$ & $\mathbf{3}$ & $\mathbf{4}$ \\
\hline 1.Food and Equipment Health Dimension & 1 & & & \\
2.Hygiene Health Dimension & $.557^{* *}$ & 1 & & \\
3.Awareness Dimension & $.600^{* *}$ & $.661^{* *}$ & 1 & \\
4.Physical Space and Environmental Health & $.447^{* *}$ & $.492^{* *}$ & $.674^{* *}$ & 1 \\
Dimension & & & &
\end{tabular}

When Table 5 is examined, it is seen that the correlation values between the dimensions of the scale vary between .447 and .674 and are meaningful at the $p<.001$ level.

\section{Discussion, Result and Suggestion}

The aim of this study is to develop a valid and reliable measurement tool that can measure the effectiveness of health management in schools in line with teachers' opinions. The validity and reliability studies conducted on the data of the study showed that the EHMSS is a psychometrically appropriate measurement tool.

CFA was conducted to determine whether the structure of EHMSS that emerged as a result of EFA could be confirmed or not. According to the CFA results, all items of the scale were found to be significant at $\mathrm{p}<.01$ level in terms of $\mathrm{t}$ values. In addition, it was determined that the correlation values between the dimensions of the scale ranged between .447 and .674 and were meaningful at the $p<.001$ level. 
Reliability analysis of the EHMSS was determined by calculating Cronbach's Alpha reliability coefficient. Cronbach's Alpha reliability coefficient was found to vary between .84 and .92 in all sub-dimensions and the EHMSS. Considering that the reliability coefficient of the measurement tools is .70 and higher in terms of the reliability of the scale data (Hair et al., 2014), it can be said that all sub-dimensions of the scale and the entire scale are reliable. As a result, according to all EFA and CFA findings of the study, it is understood that the EHMSS is a valid and reliable measurement tool that can measure the effectiveness of health management in schools.

This scale was made to emphasize how important health management is in educational institutions and various other institutions. Since good health management contributes to academic success, this area of administration should be developed at schools and should be revised systematically to meet the needs. Thus, health management should be made an important part of educational management process. Aligned with this process, seminars, webinars and other interactive organizations should be held to increase the knowledge, awareness and participation of educational administrators and teachers in order to be more productive and qualified.

In further studies, the validity and reliability study of the EHMSS can be repeated with larger and different study groups. New scale development studies regarding the effectiveness of health management of employees working in organizations other than schools can be conducted. In addition to this, it can be investigated whether the EHMSS, whose validity and reliability study was conducted according to the opinions of teachers, has the same psychometric properties by taking the opinions of school administrators, parents, students or other school stakeholders.

\section{References}

Adindu, A. (2013). The need for effective management in African health systems. Journal of Health Management, 15(1), 1-13.

Arbucle, J. L. (2007). Amos 16.0 user's guide. SPSS Inc.

Babayiğit, M. A., Bakır, B., Tekbaş, Ö. F., Oğur, R., Kılıç, A., \& Hasde, M. (2010). Ankara Keçiören ilçe milli eğitim müdürlüğüne bağlı ilköğretim okullarının çevre sağlığı standardına uygunluk durumunun değerlendirilmesi. Türkiye Halk Sağllğg Dergisi, 8(1), 19-29.

Balc1, A. (2015). Sosyal bilimlerde araştırma yöntem, teknik ve ilkeler. Pegem Akademi Yayıncilik.

Baltaş, Z. (2004). Să̆lık psikolojisi halk să̆ğı̆̆ında davranış bilimleri. Remzi Kitabevi.

Bektaş, M., \& Öztürk, C. (2008). Effect of health promotion education on presence of positive health behaviors, level of anxiety and self concept. Social Behavior and Personality 36(5), 681-690. 
Bayram, N. (2013). Sosyal bilimlerde SPSS ile veri analizi (4. bask1). Ezgi Kitabevi.

Bonell, C., Humphrey, N., \& Campbell, R. (2014). Why schools should promote students' health and Wellbeing. British Medical Journal, 348, g3078. doi: 10.1136/bmj.g3078. PMID: 25134103.

Brown, T. A. (2006). Confirmatory factor analysis for applied research. The Guilford Press.

Bryman, A., \& Cramer, D. (2001). Quantitative data analysis with SPSS release 10 for windows: A guide for social scientists. Routledge.

Bulduk, S. (2002). Okul sağlı̆̆l hemşireliğinin durumu ve işlevsel boyutu (Yayımlanmamış yüksek lisans tezi). Marmara Üniversitesi Sağlık Bilimleri Enstitüsü.

Bundy, D. A. P., Silva, N.D., Horton, S., Patton, G. C., Schultz, L., \& Jamison, D. T. (2017). Investment in child and adolescent health and development: key messages from Disease Control Priorities. Lancet, 391(10121):687-699.

Byrne, B. M. (2001). Structural equation modeling with LISREL, PRELIS, and SIMPLIS: Basic concepts, applicaitons, and programming. Erlbaum.

Claing, G. J., \& Rossor, E. B. (1999). Health assesment at school entry: performance of a system based on school nurse interviews. Child: Care, Health and Development, 25(6), 421-428.

Comrey, A. L., \& Lee, H. L. (1992). A first course in factor analysis. Erlbaum.

Constante, C. C. (2001). School health nursing. Journal of School Nursing, 17(1), 3-11.

Croghan, E., \& Johnson, C. (2004). Occupational health and school health: a natural alliance? Nursing and health care management and policy. Journal of Advanced Nursing, 45(2), 155-161.

Çakır, S. (2005). Kocaeli ilinde okul sağlı̆̆ ve hemşireliği hizmetlerinin durumu (Yayımlanmamış bilim uzmanlığı-master tezi). Kocaeli Üniversitesi Sağlık Bilimleri Enstitüsü.

Çelik, A. H. (2009). Yapısal eşitlik modellemesi ve bir uygulama: Genişletilmiş online alışveriş kabul modeli (Yayımlanmamış doktora tezi). Osmangazi Üniversitesi Fen Bilimleri Enstitüsü.

Dağdeviren, Z. (2010). Şanlıurfa il merkezindeki lise öğrencilerinin să̆lı̆̆ geliştirme davranışları ve ilişkili faktörler (Yayımlanmamış yüksek lisans tezi). Harran Üniversitesi Sağlık Bilimleri Enstitüsü. 
Durlak, J. A., \& Weissberg, R. P., Dymnicki, A. B. (2011). The impact of enhancing students' social and emotional learning: a meta-analysis of school-based universal interventions. Child Development, 82, 405-32.

Gençoğlu, P., \& Kuşkaya, S. (2017). Türkiye'de sağlı̆̆ın eğitim üzerindeki etkileri: ARDL sınır testi yöntemi ile bir değerlendirilme. İşletme ve Íktisat Çalışmaları Dergisi, 5(4), 1-11.

Hair, J. F., \& Black, W. C., Babin, B. J., \& Anderson, R. E. (2014). Multivariate data analysis. Pearson New International Edition (7th ed.).

Hatipoğlu, S. (2016). Manisa Şehzadeler Eğitim Araştırma Toplum Sağlı̆̆ı Merkezi bölgesinde okul sağlı̆̆ı düzeyinin tanımlanması (Yayımlanmamış uzmanlık tezi). Celal Bayar Üniversitesi Halk Sağlığı Anabilim Dalı.

Johansen, A., Rasmussen, S., \& Madsen, M. (2006). Health behaviour among adolescents in Denmark: Influence of school Scandinavian. Journal of Public Health, $34,32-40$.

Karasar, N. (2012). Bilimsel araştırma yöntemi. Nobel Akademi Yayıncılık.

Kline, R. B. (2005). Principles and practice of structural equation modeling: Methodology in the social sciences. The Guilford Press.

Koçoğlu, D. (2011). Kapsaml okul să̆lı̆̆l hemşireliği hizmetlerinin öğrencilerin akademik performansına etkisinin değerlendirilmesi (Yayımlanmamış doktora tezi). Hacettepe Üniversitesi Sağlık Bilimleri Enstitüsü.

Kub, J., \& Steel, S. A. (2000). School health. In C. M. Smith, F.A. Maurer (Eds.), Commumity health nursing theory and practice. (811-841). WB. Saunders Company, Second edition.

Marcoulides, G., \& Schumacher, R. (2001). New developments and techniques instructural equation modeling. Lawrence Erlbaum Associates.

Marmaris, Ü. (2004). Tekirdă̆ il merkezindeki ilköğretim okullarında okul să̆lı̆̆l hizmetlerinin durumu, gereksinimler ve geleceğe yönelik öneriler (Yayımlanmamış yüksek lisans tezi). Trakya Üniversitesi Sağlık Bilimleri Enstitüsü.

MEB ve SB (2016). Okulda Sağlı̆̆ın Korunması ve Geliştirilmesi Programı. Erişim: https://hsgm.saglik.gov.tr/tr/cocukergen-sgp1/sagl\%C4\%B1g\%C4\%B1ngelisitirlmesi/okulda-sa\%C4\%9Fl\%C4\%B1\%C4\%9F\%C4\%B1nkorunmas\%C4\%B1-ve-geli\%C5\%9Ftirilmesi-program\%C4\%B1.htm, 17.10.2019.

Meydan, C. H., \& Şeşen, H. (2011). Yapısal eşitlik modellemesi AMOS uygulamaları. Detay Yayıncılık. 
Mumcu, H. K. (1999). İlkokul öğrencilerinin büyüme-gelişme ve beslenme durumunun değerlendirilmesi. VII. Ulusal Hemşirelik Kongresi Bildirileri Kitabı. Erzurum, 260262.

Murray, N. G., Low, B. J., Hollis, C., Cross, A.W., \& Davis, S. M. (2007). Coordinated school health programs and academic achievement: a systematic review of the literature. The Journal of School Health, 77, 589-600.

Oral, I., \& Mcgivney, E. J. (2014). Türkiye eğitim sisteminde eşitlik ve akademik başarı araştırma raporu ve analiz. Eğitim Reformu Girişimi. İstanbul: Sabancı Üniversitesi.

Özcan, C., Kılınç, S., \& Gülmez, H. (2013). Türkiye'de okul sağlı̆̆ı ve yasal durum. Ankara Medical Journal, 13(2), 71-81.

Özyurt, B. (2004). Manisa kent merkezinde okul sağllğg düzeyinin tanımlanması (Yayımlanmamış uzmanlık tezi). Celal Bayar Üniversitesi Halk Sağlığı Anabilim Dali.

Pelin Başar, R. (2008). Aydın'da iki ilköğretim okulunda okul sağlı̆̆ hizmetleri ve yeni bir model geliştirilmesi (Yayımlanmamış uzmanlık tezi). Adnan Menderes Üniversitesi Halk Sağlığı Anabilim Dalı.

Schainker, E., O’Brien, M. J., Fox, D., \& Bauchner, H. (2005). School nursing services: use in an urban pablic school system. Archives of Pediatrics \& Adolescent Medicine, $159(1), 83-87$.

Schermelleh-Engel, Moosbrugger, H., \& Müler, H. (2003). Evaluatingthe fit of structural equation models: tests of significanceand descriptive goodness-of-fit measures. Methods of Psychological Research Online, 8(2), 23-74.

Serim, M., \& Aslan, H. (1991). İlkokul öğrencilerinde görme kusurları ve okul başarısı ile ilişkisi (Düz.: O. Hayran, S. Aksayan, \& M. Kayhan). Halk sağlığı araştırma özetleri. (s. 86-88). Marmara Üniversitesi Yayınları.

Shackleton, N., Jamal, F., Viner, R. M., Dickson, K., Patton, G. C., \& Bonell, C. (2016). School-level interventions to promote adolescent health: systematic review of reviews. Journal of Adolescent Health, 58, 382-96.

Soysal, A., Giray, H., \& Şevken, S. (2008). İzmir Kemalpaşa ilçesindeki ilköğretim okullarının çevre sağlığı açısından değerlendirilmesi. TAF Preventive Medicine Bulletin, 7(5), 385-390.

Sümer, N. (2000). Yapısal eşitlik modelleri: temel kavramlar ve örnek uygulamalar. Türk Psikoloji Yazllarl, 3(5), 49-74.

Şahinöz, T., Şahinöz, S., \& Kıvanç, A. (2017). Sağlığı geliştirmenin en kolay yolu: okul sağlığı. Gümüşhane Üniversitesi Sağllk Bilimleri Dergisi, 6(4), 303-312. 
Şencan, H. (2005). Sosyal ve davranışsal ölçümlerde güvenilirlik ve geçerlilik. Seçkin Yayıncilik.

Şimşek, Ö. F. (2007). Yapısal eşitlik modellemesine girişs: temel ilkeler ve lisrel uygulamalarl. Ekinoks Yayınları.

Tabachnick, B. G., \& Fidell, L. S. (2013). Using multivariate statistics. Pearson.

Tavşancıl, E. (2010). Tutumların ölçülmesi ve spss ile veri analizi. Nobel Yayıncılık.

Tezel, A., \& Yaman, S. (1998). Erzurum ili ilkokul 4. ve 5. sınıf çocuklarının ağız ve diş sağlığı konusundaki bilgi, tutum ve davranış düzeyinin araştırılması. Atatürk Üniversitesi Hemşirelik Yüksekokulu Dergisi, 1(1), 36-45.

Thompson, J. M. (2012). The strategic management of human resources. In Buchbinder, S. B. \& Shanks, N. H. (Eds). Introduction to health care management. Second Edition, Jones \& Bartlett Learning.

Ulusoy H., Tosun N., \& Aydın, J. C. (2014). Türkiye'de sağlık yönetimi alanında lisans eğitimini sürdürmekte olan öğrencilerin genel profilinin belirlenmesine yönelik bir çalışma. 7.Ulusal Sağllk ve Hastane İdaresi Kongresi, Konya, s:10-22.

Usta, İ. (2008). Tokat ili Erbaa ilçe merkezi ilköğretim okullarındaki okul sağll̆̆g hizmetlerinin değerlendirilmesi (Yayımlanmamış doktora tezi). Erciyes Üniversitesi Sağlık Bilimleri Enstitüsü.

Watson, M. (2008). Going for gold: the health promoting general practice. Quality in Primary Care, 16, 177-185.

Yavuz, S. (2005). Developing a technology attitude scale for pre-service chemistry teachers, The Turkish Online Journal of Educational Technology, 4(1), 17-25. 
Appendix: Effectiveness of Health Management in Schools Scale

\begin{tabular}{|c|c|c|c|c|c|c|}
\hline $\begin{array}{l}0 \\
\dot{0}\end{array}$ & $\begin{array}{l}\text { Explanation: } \\
\text { Please answer the scale questions by putting the phrase "In our school". }\end{array}$ & 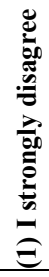 & 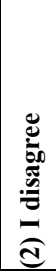 & 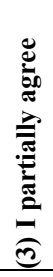 & 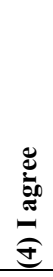 & 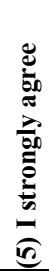 \\
\hline \multicolumn{7}{|c|}{ In our school; } \\
\hline 1 & ...foods that pose a health threat are sold. $(*)$ & $(1)$ & $(2)$ & (3) & $(4)$ & $(5)$ \\
\hline 2 & ...food residues are stored under suitable conditions. & $(1)$ & $(2)$ & (3) & $(4)$ & $(5)$ \\
\hline 3 & & $(1)$ & $(2)$ & (3) & $(4)$ & $(5)$ \\
\hline 4 & & $(1)$ & $(2)$ & (3) & $(4)$ & $(5)$ \\
\hline 5 & & $(1)$ & $(2)$ & (3) & $(4)$ & $(5)$ \\
\hline 6 & & $(1)$ & $(2)$ & (3) & $(4)$ & $(5)$ \\
\hline 7 & & $(1)$ & $(2)$ & (3) & $(4)$ & $(5)$ \\
\hline 8 & ...students follow the general hygiene rules. & $(1)$ & $(2)$ & (3) & $(4)$ & $(5)$ \\
\hline 9 & $\begin{array}{l}\text {...necessary measures are taken to prevent the spread of infectious } \\
\text { diseases. }\end{array}$ & (1) & $(2)$ & (3) & (4) & $(5)$ \\
\hline 10 & & $(1)$ & $(2)$ & (3) & $(4)$ & $(5)$ \\
\hline 11 & & $(1)$ & $(2)$ & (3) & (4) & $(5)$ \\
\hline 12 & $\begin{array}{l}\text {...the school administration organizes informative trainings and } \\
\text { seminars on school health. }\end{array}$ & (1) & $(2)$ & (3) & (4) & (5) \\
\hline 13 & $\begin{array}{l}\text {...the school administration takes necessary measures to protect school } \\
\text { health. }\end{array}$ & (1) & $(2)$ & (3) & $(4)$ & $(5)$ \\
\hline 14 & & $(1)$ & $(2)$ & (3) & $(4)$ & $(5)$ \\
\hline 15 & & $(1)$ & $(2)$ & (3) & $(4)$ & $(5)$ \\
\hline 16 & ...the colors of the classroom and corridors are psychologically relaxing. & $(1)$ & $(2)$ & $(3)$ & $(4)$ & $(5)$ \\
\hline 17 & ...classrooms have suitable conditions in terms of heat and light. & $(1)$ & $(2)$ & (3) & $(4)$ & $(5)$ \\
\hline 18 & ...there is enough green area. & $(1)$ & $(2)$ & (3) & $(4)$ & $(5)$ \\
\hline 19 & & $(1)$ & $(2)$ & (3) & (4) & $(5)$ \\
\hline 20 & & $(1)$ & $(2)$ & (3) & $(4)$ & $(5)$ \\
\hline 21 & & $(1)$ & $(2)$ & (3) & $(4)$ & $(5)$ \\
\hline 22 & & $(1)$ & $(2)$ & (3) & $(4)$ & $(5)$ \\
\hline
\end{tabular}

(*): Expresses reverse items.

\section{DIMENSIONS OF THE SCALE}

- 1.-7. Questions: Food and Equipment Health Dimension (7 questions)

- 8.-11. Questions: Hygiene Health Dimension (4 questions)

- 12.-15. Questions: Awareness Dimension (4 questions)

- 16.-22. Questions: Physical Space and Environmental Health Dimension (7 questions) 